\title{
Corporate Social Responsibility (CSR) practices of financial institution in Bangladesh: the case of United Commercial Bank
}

\author{
Sumaiya Afrin ${ }^{1}$, Farhana Sehreen ${ }^{2}$, Mohammad Rashed Hasan Polas ${ }^{3 *}$, Rubyat Sharin ${ }^{4}$ \\ Department of Marketing, Jahangirnagar University, Savar, Bangladesh ${ }^{1,2}$ \\ Institute of Scientific Research and Graduate School, Universidad de Lima, Lima, Peru ${ }^{3 *}$ \\ Graduate School of Management, International Islmic University Malaysia, Kuala Lumpur, Malaysia ${ }^{4}$ \\ sumaiya.afrin135@gmail.com ${ }^{1}$, fsehreen515@yahoo.com ${ }^{2}$, rashedhasanpalash@gmail.com ${ }^{3 *}$, \\ rubyat.sharin@gmail.com ${ }^{4}$
}

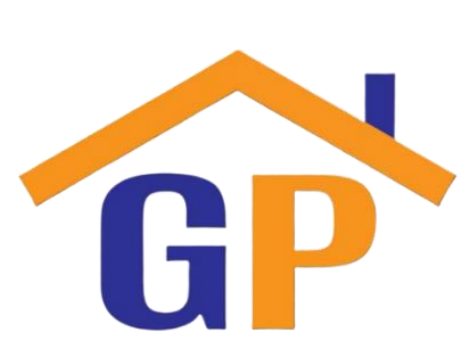

\begin{abstract}
Purpose: The main purpose of the research is to understand the CSR practices of financial institutions in Bangladesh better.

Research methodology: Corporate Social Responsibility (CSR) is concerned with businesses' interactions with society as a whole. Such CSR operations cover an organisation's fiscal, legal, ethical, and philanthropic obligations. United Commercial Bank Limited (UCB) has been chosen as the study's subject. This study is a qualitative research project that used an exploratory research design. For data collection, both main and secondary data sources were used. The in-depth interview approach with an open-ended questionnaire was used to gather primary data on CSR practices from $70 \mathrm{UCB}$ employees.
\end{abstract}

Article History

Received on 23 April 2021

$1^{\text {st }}$ Revision on 19 May 2021

$2^{\text {nd }}$ Revision on 26 May 2021

Accepted on 27 May 2021
Results: According to the findings of the study, UCB is deeply performing its fiscal, legal, ethical, and philanthropic responsibilities, but it has not expanded its philanthropic activities on a voluntary basis. Furthermore, the representation of UCB employees in CSR management is inadequate, with the exception of top-level executives.

Limitations: Any methodological issues were addressed, such as sampling challenges because financial institutions do not encourage third parties to obtain their secrets because competition occurs everywhere.

Contribution: This study makes several suggestions, such as improved and more systematic communication of CSR strategies to employees, increased investments in CSR programs, and specially targeted CSR preparation, which could assist UCB in encouraging a more successful application of its CSR strategies.

Keywords: Corporate Social Responsibility, United Commercial Bank Ltd., CSR management, Carroll's pyramid of CSR, Philanthropic

How to cite: Afrin, S., Sehreen, F., Polas, M. R. H., \& Sharin, R. (2020). Corporate Social Responsibility (CSR) practices of financial institution in Bangladesh: the case of United Commercial Bank. Journal of Sustainable Tourism and Entrepreneurship, 2(2), 69-82.

\section{Introduction}

Corporate Social Responsibility (CSR) is now a widely accepted term in most Bangladeshi corporate organisations. UCB is one of our country's first-generation banks, serving the nation for the past 34 years in the private banking market. UCB, like every other company, has a duty not only to its owners 
but also to the other partners in its corporate world (Ali et al., 2017; Alshbili \& Elamer, 2020). As a result, UCB strives to meet its societal fiscal, legal, ethical, and philanthropic obligations. Furthermore, UCB as an entity operates by cycles of human activity, and all of its activities are governed by the individuals that comprise it. As a result, it is important to consider its employees' views on UCB's CSR activities. The bank's Brand Marketing and Public Relations division oversees its CSR practices, and the bank claims to keep its staff updated and concerned with the corporate social obligations that must be met (Barakat et al., 2015; Agudelo et al., 2019).

Recognising the importance of Corporate Social Responsibility (CSR), most banks in Bangladesh have implemented social and environmental programmes to support themselves and society. Nowadays, the business community places a high value on corporate social responsibility. It is also a contemporary marketing concept that has a very positive impact on all kinds of consumers. As a result, it is critical to research the CSR activities of various businesses, banks, and financial institutions in Bangladesh. In this regard, as a well-known and big private bank in Bangladesh, the examination of UCB's CSR practices is critical (Dyduch \& Krasodomska, 2017). Since UCB has been practising CSR extensively over the past few years, no exclusive studies focused exclusively on this financial institution's CSR tactics and practices have been found to date. As a result, this review is needed to comprehend UCB's CSR practices as well as the bank's employees' role in its CSR practices (Belal et al., 2015; Donaghey \& Reinecke, 2018).

The overarching aim of this research is to provide an outline of United Commercial Bank Ltd's Corporate Social Responsibility (CSR) activities (UCB). The study also seeks to achieve particular goals such as evaluating UCB employees' opinions on the bank's CSR activities, identifying the tactics that UCB uses to meet its CSR practices, and providing guidelines for future changes. Finally, the report attempted to gain a broad understanding of the CSR practice situation of financial institutions in Bangladesh by studying United Commercial Bank Ltd's CSR practices.

Aside from direct contributions to the national exchequer by the payment of corporate income tax, UCB contributes to the country's economy by creating employment, providing funding assistance to almost all sectors, including corporate, SMEs, the RMG industry, agriculture, and, of course, individuals through a variety of creative retail goods.

Table 1. UCB's contribution to the economy

\begin{tabular}{|c|l|}
\hline Criteria & \multicolumn{1}{|c|}{ Contribution to the Economy } \\
\hline Loans & $\begin{array}{l}\text { As of 31 December 2015, UCB's total credit exposure was BDT 197.414 billion } \\
\text { with 34,897 no. of clients which were BDT 174.146 billion with 30,880 no. of } \\
\text { clients on 31 December 2014. }\end{array}$ \\
\hline Employment & $\begin{array}{l}\text { UCB and its subsidiary employed as many as 3,837 employees as of 31 December } \\
2015 \text { and in 2014, it employed 3,679 employees that increased from 2,982 } \\
\text { employees in 2011. }\end{array}$ \\
\hline Tax Payment & $\begin{array}{l}\text { During the year 2015, UCB provided a total of BDT 3,275 million for payment of } \\
\text { corporate income tax that has increased from BDT 3,166.94 million for payment of } \\
\text { corporate income tax in 2014. It also paid VAT' 015\% on the fees and commission } \\
\text { income of the bank. }\end{array}$ \\
\hline Payment of & $\begin{array}{l}\text { The Board of Directors of the bank proposed the payment of 25\% dividend to its } \\
\text { shareholders for the year 2015 and in 2014 the bank has also paid 30\% dividend that } \\
\text { had increased from 27\% dividends in 2011. }\end{array}$ \\
\hline
\end{tabular}

(Source: UCB Annual Report, 2015)

Furthermore, UCB seeks advancement without jeopardising future generations' interests, limiting and discouraging initiatives that are harmful to the environment and health. As a result, the profit interest is never prioritised over the means or method of receiving the profit. 


\section{Literature review}

Previously, corporate companies all around the world were solely concerned with increasing their earnings and sales. They used to pay no attention to the effect of their industries on society as a whole (Rana, Kalam \& Halimuzzaman, 2012). However, in today's world, maintaining these organisations' responsibility for the effect of their operations on the ecological and social environments is becoming a major phenomenon. Bangladesh Bank is the country's central bank. Bangladesh's government is in its sole possession.

As a result, business organisations are now fulfilling their responsibilities to communities and societies by taking various measures such as providing financial assistance to people, institutions, and communities in need, sponsoring various educational, social, cultural, and sporting events, and reducing pollution and waste that they leave on the environment as a result of their operations (Rana et. al., 2012). As a result, scholars have begun to examine the phenomenon of CSR practices, and they conclude that the banking sector is one of the most important sectors in Bangladesh that successfully engages in CSR practices (Rahman, 2013). The credit for such improved CSR practice can be attributed to the Bangladesh Bank (The Central Bank of Bangladesh). As previously, the banks of Bangladesh did not have any specific rules to obey in terms of CSR policies. In 2008, Bangladesh Bank issued a detailed directive titled "Mainstreaming corporate social responsibility (CSR) in banks and financial institutions in Bangladesh," which increased mandatory compliance with CSR-related practices (Hoque et al., 2018; Afshar et al., 2019; Jermsittiparsert et al., 2019; Bhattacharjee et al., $\underline{2020)}$.

Following that, several researchers studied the expenditures of various financial institutions, including banks, in their CSR operations, providing interesting insights on CSR activities in Bangladesh's banking sector. For example, Rana et al. (2012) discovered the CSR activities of Dutch-Bangla Bank Limited (DBBL) and its weaknesses in these practices and proposed some courses of action. Education, hygiene, disaster relief, and recreation are the fields in which DBBL practices and invests the most money in CSR operations. Again, Ahmed and Kayssar (2013) found that Southeast Bank Ltd. conducts CSR by strictly adhering to Bangladesh Bank guidelines. It spent BDT 36.85 million in 2012 on Education, wellness, economic welfare, environmental issues, art and culture, recreation, and other activities. As part of their CSR operations, various public banks contribute to various industries (Miajee, 2015). Agrani Bank Limited, Rupali Bank Limited, and Janata Bank Limited spent 10.41 crore BDT, 6.0 crore BDT, and 13.75 crore BDT on CSR practices in 2013, respectively (Kuo et al., 2016; Javeed \& Lefen, 2019; Uddin et al., 2018; Bhattacharjee et al., 2018; Hossain et al., 2020; Polas et al., 2020).

However, these financial institutions must also ensure that their CSR operations and expenditures are in accordance with the legislation of the Bangladesh Bank (The Central Bank of Bangladesh), which is critical in a developing country like Bangladesh. Such compliance is assured by these agencies' oversight and reporting procedures on their CSR operations. According to Masud and Hossain (2012), despite the fact that all of the banks they reviewed issued CSR activity records, they did not completely comply with the Finance Acts of 2010 and 2011. In this regard, the finance act of Bangladesh has listed and separated the areas in which financial institutions can engage in CSR operations, and it is regrettable that less than $60 \%$ of banks have contributed to those suggested areas (Polas et al., 2021). The study also showed that there are 25 listed areas where organisations are recommended to participate as part of their CSR activities, but no banks have contributed in any of these areas, and the majority of banks have contributed in just 55\% of these areas. Furthermore, the study discovered that banks reported their operations non-financial way, with just $70 \%$ of the information provided in financial words. As a result, openness and openness in these financial institutions' CSR operations are critical to achieving the maximum value that CSR initiatives are intended to bring to society. It is also critical that CSR has been critical for management and has begun to have an impact on their organisational reputation and financial results (Ahmed \& Kayssar 2013; Majeed et al., 2015; Khan et al., 2019). 
Finally, CSR has some drawbacks, as others consider the word "CSR" to be fuzzy, undefined, and intangible. Furthermore, they believe that its function is ambiguous because it creates contradictions within the organisation's different types of stakeholders (Yasmin, 2016). Since CSR is an expense for organisations, it is limited to a single country or region as a short-term strategy. Furthermore, the study stated that CSR fosters mistrust by undermining moral value due to the likelihood that the organisations' goals are mostly for advertising rather than health. As a result, it just strengthens but does not boost workers' views of the company. Nonetheless, a survey of the literature shows that banks in Bangladesh are aware of CSR operations and that their investments are growing year after year. Therefore, it is essential to ascertain the views of workers of financial institutions on their organisations' CSR operations and practices.

Table 2. UCB's expenditures for philantropic activities in different sectors of Bangladesh

\begin{tabular}{|c|c|c|c|}
\hline Sectors & $\begin{array}{c}\text { Expenditure } \\
2013\end{array}$ & $\begin{array}{c}\text { Expenditure } \\
2014\end{array}$ & $\begin{array}{c}\text { Expenditure } \\
2015\end{array}$ \\
\hline Education & $24,05,000$ & $37,45,000$ & $64,20,000$ \\
\hline Health & $10,87,000$ & $28,70,000$ & $30,50,000$ \\
\hline Environment & $1,86,000$ & - & $1,00,00,000$ \\
\hline Disaster Management & $1,21,200$ & $69,00,000$ & $3,93,09,000$ \\
\hline Art \& Culture & $2,45,000$ & $1,01,25,000$ & $17,10,000$ \\
\hline Sports & $1,16,20,000$ & $1,02,06,000$ & $11,80,000$ \\
\hline Socio Economic Development & $1,26,20,000$ & $1,42,75,000$ & $1,65,50,000$ \\
\hline Others including Environment & $6,05,000$ & $5,50,000$ & $9,73,500$ \\
\hline Total BDT & $\mathbf{2 , 8 8 , 8 9 , 2 0 0}$ & $4,86,71,000$ & 7,91,92,500 \\
\hline
\end{tabular}

(Source: UCB Annual Report, 2015)

\section{Research methodology}

This study is a qualitative research study that used an exploratory research design. For data collection, both main and secondary data sources were used. Extensive secondary data analysis was carried out using data from UCB's internal records, past annual reports, and publications. To meet the requirement of qualitative analysis, a list of relevant publications from various journals and academic websites was also used to establish a basic understanding of the CSR practices of various financial institutions in Bangladesh. The in-depth interview approach with an open-ended questionnaire was used to gather primary data on CSR activities from 70 UCB employees. This research was carried out at UCB's Corporate Office in Gulshan, Dhaka, using a judgmental sampling method to select respondents for in-depth interviews from workers employed in the Brand Marketing \& Corporate Affairs, Human Resource \& Management, Board \& Share, and Internal Control \& Compliance divisions.

The questionnaire consists of twenty questions. The first five questions assess the demographic variables indicated, which are gender, age, Education, marital status, and monthly income. The sample population includes all employees from UCB's Brand Marketing \& Corporate Affairs, Human Resource \& Management, Board \& Share, and Internal Control \& Enforcement divisions in Dhaka, Bangladesh. Each randomly selected respondent received the questionnaire individually. The questionnaire was distributed by the researchers to those who wished to participate in the survey. Following that, $73 \%$ of them were under the ages of (25 years-35years). Most of them were postgraduates at the time. Most interestingly, 46 per cent of those polled were single. Researchers recorded the interviews with digital devices and transcribed them from word to word and coded the 
transcription manually to discover the main themes from the interviews responses (HessBiber, 2017). It has taken 30-40 minutes long fro per interviews. In addition, the researchers used themes to analyse the data in relation to the objectives.

\section{Results and discussions}

\subsection{Corporate Social Responsibility (CSR) practices in Bangladesh}

Bangladesh Bank's DOS (Department of Off-site) Circular No. 01, dated 1 June 2008, titled "Mainstreaming Corporate Social Responsibility (CSR) in Banks and Financial Institutions," gives concise guidance on CSR. It focused on criteria such as corporate governance, workplace environment, the environmental impact of business activities, market environment (engagement with borrowers), financial inclusion (e.g. investment in development areas, amount of investment, and a number of beneficiaries), social projects and community investment (e.g. Education, health, disaster management, environment, sports, art \& culture).

According to Rezaul (2017), the total amount of CSR investment by banks and non-bank financial institutions (NBFIs) in the fiscal year (FY) 2014-15 as recorded by Bangladesh Bank was more than BDT 54 billion. In the fiscal year, NBFIs announced a direct CSR expenditure of BDT 44.2 million. Education, welfare, humanitarian, and disaster relief accounted for 34.5 per cent, 21.8 per cent, and 23.5 per cent of the banks' overall CSR contributions during the time, respectively. Cultural welfare received the most attention from NBFIs (24.8 per cent), followed by humanitarian and disaster relief (22.7 per cent) and other industries (27.7 per cent). Education, health, and the environment were given less attention in FY15, with NBFIs spending 11.6 per cent, 7.4 per cent, and 5.8 per cent, respectively. In addition, NBFIs focused less on infrastructure growth in underserved areas and income-generating programs for the vulnerable. Furthermore, the Bank and Financial Institutions Division (BFID) of Bangladesh's Ministry of Finance is preparing to launch new CSR guidance that prioritises the country's health, education, climate, stability, and child welfare sectors as a strategy to achieve the Sustainable Development Goals (SDGs) (Moktadir et al., 2018; Mahmud et al., 2020).

\subsection{Theoretical approach}

Archie B. Carroll provided a four-layered pyramid that depicts an organisation's corporate social responsibility. Carroll (1991) defines corporate social responsibility as "the operation of an enterprise in such a way that it is commercially efficient, law-abiding, legal, and socially supportive."

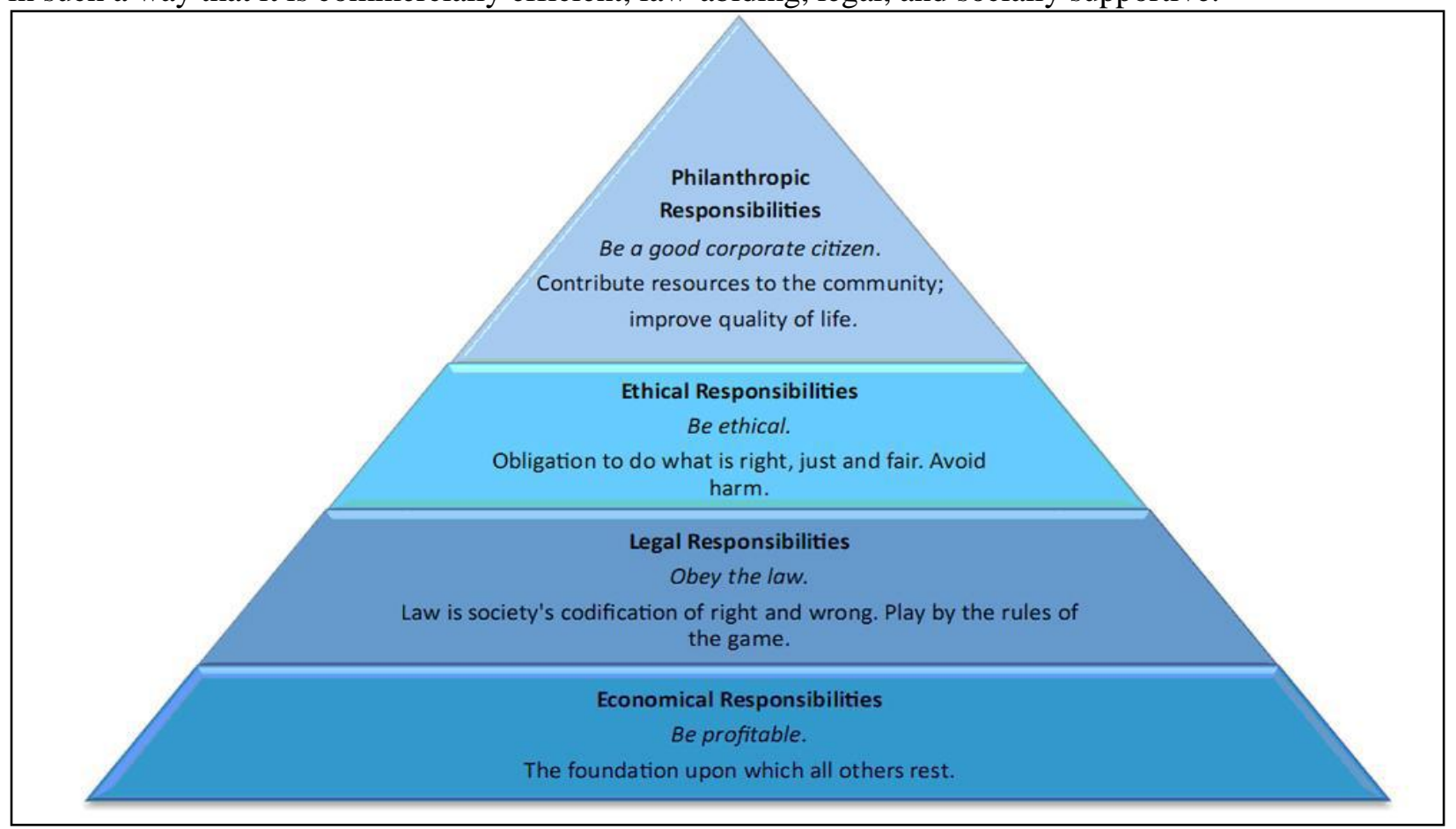

Figure 1. Carroll's Pyramid of CSR 
A corporate enterprise indeed has to provide society with what it requires in return for resources to generate income. This duty comes in the category of fiscal responsibility. Another duty that businesses must carry on is to uphold the rules to fulfil their legal obligations. On the other hand, businesses must concentrate on ethical accountability by meeting people's expectations and adhering to the other obligations mentioned above. Another type of responsibility is philanthropic responsibility, which reaches out to society by improving the lifestyle of the people in the city, particularly by donations to various organisations and various types of social activities.

\subsection{Corporate Social Responsibility (CSR) practices of $U C B$}

UCB aims to follow the latest idea of assessing success based on economic effect, social impact, and environmental impact. Every year, UCB submits its CSR report to Bangladesh Bank in the format specified by the bank, which includes its compliance with the guidelines as well as the financial assistance and donations given by the bank to various sectors in Bangladesh.

\subsubsection{Philanthropic responsibilities}

UCB has always agreed to contribute to growth by donating to and sponsoring various philanthropic causes. It aspires to create a social business model rather than relying only on commercial business objectives. The investments of UCB for philanthropic efforts in various sectors of the world in the years 2013 to 2015 are outlined as a cumulative number in the table below (Perry et al., 2015). In the following Table 2, it can be shown that UCB's total expenses on CSR practices for philanthropic purposes rose steadily year after year. Though total expenditures in sports and arts and arts sectors were lower in 2015 than in previous years, total expenditures in all other sectors rose. Such increased spending demonstrates UCB's dedication to conducting socially conscious business operations (Rao \& Tilt, 2016). Followings are several sectors where UCB focuses on fulfilling its philanthropic responsibility:

\subsubsection{Education}

UCB has always considered Education to be the most potent instrument for Bangladesh's long-term growth. Its general emphasis is on offering scholarships and financial assistance to needy, underprivileged, and brilliant students and grants to educational institutions. It also supports debating classes, knowledge-enhancement conferences, job fairs, art contests, and science fairs, among other things. UCB has made the following contributions to the education sector:

Table 3. Some contributions of UCB to the Education sector of Bangladesh

\begin{tabular}{|c|c|c|c|}
\hline \multicolumn{2}{|c|}{ Criteria } & Institution & $\begin{array}{l}\text { Amount } \\
\text { (BDT) }\end{array}$ \\
\hline \multirow{4}{*}{$\begin{array}{l}\text { Financial } \\
\text { Assistance }\end{array}$} & \multirow{4}{*}{$\begin{array}{l}\text { Educational } \\
\text { Institutions }\end{array}$} & Dhaka Mohila College. & $25,00,000$ \\
\hline & & Anowarul Azim Girls High School, Chittagong. & $3,00,000$ \\
\hline & & K F Karim Bohumukhi High School, Faridpur. & $3,00,000$ \\
\hline & & Naogaon Govt College & 15,000 \\
\hline \multirow{5}{*}{ Donation } & Construction Work & $\begin{array}{c}\text { Chandgaon Shamsher primary school \& Hajigonj } \\
\text { Barumchara High School }\end{array}$ & $8,00,000$ \\
\hline & $\begin{array}{l}\text { Computers (10) \& } \\
\text { Printer (1) }\end{array}$ & Banskhali Girls College, Chittagong & $2,90,000$ \\
\hline & $\begin{array}{c}\text { Classroom } \\
\text { Renovation \& } \\
\text { Equipment Support }\end{array}$ & $\begin{array}{c}\text { Department of Development Studies, Dhaka } \\
\text { University }\end{array}$ & $15,00,000$ \\
\hline & $\begin{array}{c}\text { Learning Disability } \\
\& \text { Behavioral } \\
\text { Support }\end{array}$ & Frobel Play School & 25,000 \\
\hline & Debate Practice & National IT Debate Championship & $3,00,000$ \\
\hline
\end{tabular}

(Source: UCB Annual Report, 2015) 
UCB's net investments in the education sector as a percentage of its total spending in philanthropic activities rose to 8.32 per cent in 2015 , up from 7.69 per cent in 2014 . However, the 7.69 per cent in 2014 fell from 8.11 per cent in 2013.

\subsubsection{Health}

UCB has contributed to various initiatives aimed at improving the health system in Bangladesh over the years. It provides financial assistance to the vulnerable and destitute for health-related matters and grants to healthcare institutions and non-profit organisations that focus on child health, autism, and underprivileged youth. The following are some of UCB's contributions to the health sector:

Table 4. Some contributions of UCB to the Health sector of Bangladesh

\begin{tabular}{|c|c|c|c|}
\hline \multicolumn{2}{|c|}{ Criteria } & Institution/Individuals & $\begin{array}{c}\text { Amount } \\
\text { (BDT) }\end{array}$ \\
\hline \multirow{3}{*}{ Donation } & Ambulance & Bangladesh Ship Breakers' Association Hospital & $1,00,000$ \\
\cline { 2 - 4 } & Construction & Laxmipur Diabetic Society & $25,00,000$ \\
\cline { 2 - 4 } & Medical Facilities & Society For Rehabilitation Of Autistic Children & 25,000 \\
\hline \multirow{3}{*}{$\begin{array}{c}\text { Financial } \\
\text { assistance }\end{array}$} & Skin Cancer & Mr. Firoz Baperi & 25,000 \\
\cline { 2 - 4 } & Spinal Injury & Mr. Khurshid Alam & 50,000 \\
\cline { 2 - 4 } & Liver Problem & Mr. Sahabuddin & 50,000 \\
\cline { 2 - 4 } & Bypass Surgery & Mr. Ohiduzzaman & 50,000 \\
\cline { 2 - 4 } & Cancer Patient & Mr. Sahidul Islam & 50,000 \\
\hline
\end{tabular}

(Source, UCB Annual Report, 2015)

In 2015 , net spending as a percentage of gross expenditure rose to 3.85 per cent, up from 3.76 per cent in 2014. Though UCB's gross expenses in the health sector rose steadily over the previous two years in 2015, net spending as a percentage of gross expenditure fell from 5.90 per cent in 2014 to 3.85 per cent in 2015. (Shen et al., 2015).

\subsubsection{Disaster management}

UCB still responds quickly by offering financial assistance to government and non-government relief and welfare funds for victims of natural disasters such as storms, floods, earthquakes, harsh winters, and so on. The following are some of UCB's contributions to emergency management:

Table 5. Some contributions of UCB to the Disaster Management sector of Bangladesh

\begin{tabular}{|c|c|c|c|}
\hline \multicolumn{2}{|c|}{ Criteria } & Institution/Individuals & $\begin{array}{c}\text { Amount } \\
(\text { BDT })\end{array}$ \\
\hline \multirow{4}{*}{ Donation } & Earthquake & Earthquake affected people of Nepal & $10,000,000$ \\
\cline { 2 - 4 } & Flood & Flood affected area of Chokoria & $7,00,000$ \\
\cline { 2 - 4 } & Landslide & Landslide area of Cox's bazaar & $18,00,000$ \\
\cline { 2 - 4 } & Flood & 5 sack of rice for flood affected people of Dohazari & 9,000 \\
\cline { 2 - 4 } & $\begin{array}{c}\text { Cold wave in } \\
\text { Winter }\end{array}$ & $\begin{array}{c}\text { Blanket distribution to poor people } \\
\text { (In 2 phases) }\end{array}$ & $15,000,000$ \\
\hline
\end{tabular}

(Source: UCB Annual Report, 2015)

Per year, UCB's net disaster response spending as a percentage of gross expenditure rose from 0.42 per cent in 2013 to 14.18 per cent in 2014, and finally to 46.64 per cent in 2015.

\subsubsection{Sports}

UCB has always been a big supporter of sports growth. Over the past few years, UCB has been a huge supporter of the success of the "Football," "Hockey," and "golf" sectors. Its primary goal is to financially help the growth of global sports such as football, hockey, cricket, and golf. The following are some of UCB's contributions to the sports sector: 
Table 6. Some contributions of UCB to the Sports sectors of Bangladesh

\begin{tabular}{|c|c|c|c|}
\hline \multicolumn{2}{|c|}{ Criteria } & Institution/Individuals & Amount \\
\hline \multirow{4}{*}{ Donation } & \multirow{2}{*}{ Football } & Jahangirnagar University football team & 10,000 \\
\hline & & Abahani Krira Chakra, Faridpur & 50,000 \\
\hline & \multirow[t]{2}{*}{ Cricket } & ULAB Fair Play Cup T20 Cricket Tournament & 30,000 \\
\hline & & Bankers' Club Cricket tournament, Rajshahi & 20,000 \\
\hline Sponsorship & Cricket & Bangladesh Vs Zimbabwe Cricket series 2014 & $10,00,000$ \\
\hline
\end{tabular}

(Source: UCB Annual Report, 2015)

The overall investment in sports fell over the three years from 2013 to 2015, resulting in a drop in net expenditure as a proportion of gross expenditure in philanthropic activities to 1.49 per cent in 2015, down from 21 per cent in 2014 and 40.22 per cent in 2013. (Tilt, 2016).

\subsubsection{Arts \& Culture}

Throughout the year, UCB contributes to the arts and culture. It tries to contribute to the arts and culture field by providing financial assistance to various cultural organisations, organisations, and institutions that seek to cultivate art and culture by supporting local cultural practices, among other things. UCB has made the following contributions to the arts and culture sector:

Table 7. Some contributions of UCB to the Arts \& Culture sector of Bangladesh

\begin{tabular}{|c|c|c|c|}
\hline & Criteria & Institution/Individuals & $\begin{array}{c}\text { Amount } \\
\text { (BDT) }\end{array}$ \\
\hline \multirow{5}{*}{ Donation } & Cultural Event & 'Lakho konthe Jatiyo Songeet' & $1,00,00,000$ \\
\hline & Construction & Raozan Shilpokala Academy & $6,00,000$ \\
\hline & Media & Documentary Film on Bangladesh & $5,00,000$ \\
\hline & $\begin{array}{l}\text { The Celebration of } \\
\text { Independence Day }\end{array}$ & District Administration of Jessore & 5,000 \\
\hline & Music & $\begin{array}{c}\text { Saira Shaheed CD Album launching program } \\
\text { of Bodhon Abriti Parishad }\end{array}$ & $1,00,000$ \\
\hline
\end{tabular}

(Source: UCB Annual Report, 2015)

In 2015, UCB's net spending on arts and culture declined, as did its share of gross expenditure on philanthropic programs. It was 21 per cent in 2014, up from 0.85 per cent in 2013 , but fell to 2.16 per cent in 2015.

\subsubsection{Socio-economic development}

To build a stable Bangladesh, UCB works on various areas such as community growth, SME (Small and Medium Enterprises) entrepreneurship, textile industry, women empowerment, tourism, and so on. It is often supportive of both the government and non-governmental organisations that contribute to socio-economic growth within their respective scopes. The following are some of UCB's most recent contributions to the socio-economic development sector:

Table 8. Some contributions of UCB to the Socio-economic development of Bangladesh

\begin{tabular}{|c|c|c|c|}
\hline \multicolumn{2}{|c|}{ Criteria } & Institution/Individuals & $\begin{array}{c}\text { Amount } \\
\text { (BDT) }\end{array}$ \\
\hline \multirow{7}{*}{$\begin{array}{c}\text { Non-profit } \\
\text { organization }\end{array}$} & Change Foundation (Natore) & $2,00,000$ \\
\cline { 2 - 4 } & Association & Noakhali Bar Association & 13,500 \\
\cline { 2 - 4 } & Pure Water & Installation of Tube wells in the salty area of Pirojpur & 50,000 \\
\cline { 2 - 4 } & \multirow{4}{*}{$\begin{array}{c}\text { Construction } \\
\text { Wonation }\end{array}$} & Lalbagh Chan Tara Masjid & 50,000 \\
\cline { 3 - 4 } & Work & Hazrat Shah Abdur Rahman Wakuff jame Masjid & $5,00,000$ \\
\cline { 3 - 4 } & & Parbatnagar Jam e Masjid & 50,000 \\
\cline { 3 - 4 } & &
\end{tabular}




\begin{tabular}{|c|c|c|c|}
\hline & Babasree Kendrio Jam e Masjid & $2,00,000$ \\
\cline { 2 - 4 } & Cooperative & Satkania Lohagara Samity, Dhaka & $1,00,000$ \\
\cline { 2 - 3 } & Bnsolvent & Distribution of 30000 pamity, Dhaka & $2,00,000$ \\
\cline { 2 - 3 } & Community & Distribution of 10000 pcs of Lungis for poor people & $1,02,00,000$ \\
\cline { 3 - 4 } & & $24,00,000$ \\
\hline
\end{tabular}

(Source: UCB Annual Report, 2015)

Despite the fact that UCB's overall spending on socio-economic development rose per year from 2013 to 2015, the net expenditure as a percentage of gross expenditure on philanthropic activities declined. It fell to 20.90 per cent in 2015, from 29.33 per cent in 2014 and 43.86 per cent in 2013.

\subsubsection{Environment}

UCB has long been an active participant in environmental activities. It supports different causes in this field by taking actions or contributing to programs to conserve the climate or ecosystem, raising concerns about climate change and environmental degradation (tree planting, seminars on ecological sustainability, disaster relief initiative/support, etc.), and making efforts to move towards a greener environment through its banking activities. UCB has made the following contributions to environmental sustainability:

- Donation to the Prime Minister's Relief Fund in support of a healthy climate $(10,000,000$ BDT).

- In January and 2011, UCB, in collaboration with Bangladesh Poribesh Andolon (BAPA) and Bangladesh Environment Network (BEN), organised special conferences on "Urbanization, Traffic, Land, and Environment" in Dhaka in collaboration with various universities and environmental organisations. In 2013, it also hosted the Annual Botanical Conference in Chittagong.

- UCB also made numerous donations to the Department of Soil, Water, and Ecology (Dhaka University) and the Forestry \& Wood Technology Discipline (Khulna University) in order to improve their environmental science work.

Net spending as a proportion of gross investment rose to 12.63 per cent in 2015, up from 0.64 per cent in 2013. Notably, UCB announced no spending for environmental sustainability in 2014. As a result, it can be inferred that the net spending of UCB as a percentage of gross expenditure on philanthropic activities rose in four sectors, including education, health, disaster relief, and the environment, but decreased in three sectors, including leisure, arts and culture, and socio-economic growth. Total investment in athletics and arts and culture fell among the last three sectors. While overall spending on socio-economic development rose year after year, the net percentages of gross expenditure on philanthropic programs in this field decreased.

\subsubsection{Legal responsibilities}

UCB follows the rules and legislation of both the Bangladesh Securities and Exchange Commission (BSEC) and the Bangladesh Bank (BB). The bank adds a detailed enforcement status of the guidance issued by these regulatory agencies to its annual report. To meet Bangladesh Bank's requirements, the bank has a CEO who maintains compliance with the Bank Companies Act, 1991 and/or other applicable laws and regulations, and who also reports any violations of this Act to Bangladesh Bank (Mocan et al., 2018).

UCB files the official financial statements and has issued annual reports over the years to keep clients up to date with its recommendations on future planning and policies. It has its own Risk Management Committee, Internal Control \& Compliance Division, and Learning \& Development Center (LDC) to educate staff. Furthermore, UCB obtains an "Enforcement Certificate on Corporate Governance Guidelines" from a professional Chartered Accountant company and communicates it to shareholders to ensure ethical compliance (Muttakin et al., 2018). 


\subsubsection{Ethical responsibilities}

UCB stresses the significance of an effective Code of Conduct and Ethics Policy in promoting equitable and ethical practices for all persons participating in the banking institution. The key features of UCB's Code of Conduct and Ethics Policy, which applies to anyone who works at the bank, including maintaining the confidentiality and accuracy of financial books, records, accounts, and reports of bank transactions, avoiding conflicts with the interests of the bank and its customers, reporting frauds, theft, or significant illegal activity, and ensuring compliance with existing laws. It also specifically forbids the use of outside coercion, the reception of gifts and entertainment, and any kind of occupational bullying, intimidation, or abuse (Omran \& Ramdhony, 2015). Furthermore, a course is included in the workers' Foundation Training Course to assist them in learning and implementing the values of the Code of Conduct and Ethics Policy. Furthermore, any violation of these rules of conduct and ethics laws is sanctioned, and in severe circumstances, jobs is terminated.

\section{Results}

Questions in the in-depth interviews concentrated on UCB employees' perceptions of the bank's CSR practice and management. The below are the main conclusions from the in-depth interviews: Employees of UCB believe that the bank fulfils its economic obligations, but since there is less job stability, the increased jobs provided by UCB is becoming less sustainable. They also assume that UCB acts in accordance with the applicable laws and regulations. UCB has a formal Code of Conduct and Ethics guidelines in place, and these rules are still enforced. However, workers believe that little focus is placed on the importance of the repercussions of violating those policies in the workplace.

Furthermore, employees have often replied that UCB does not use a bottom-up system when developing CSR plans, implying that lower-level employees' CSR management recommendations are ignored. On the other hand, employees have replied that they are told about CSR strategies about legal and ethical practices during various training courses. Some respondents stated that UCB should participate in agreements to ensure women's empowerment, rural women's growth, and the welfare of single mothers. More contribution has been encouraged by respondents for orphans, minority community, and the homeless population. Respondents have also urged UCB to focus on the development projects for farmers in the rural areas of Bangladesh.

\section{Discussions and conclusions}

Banking business activities have recently been accelerated, with much scrutiny and critique. Banking companies operating across national borders of several countries are no longer willing to carry out disruptive and unethical operations within protection radars at the time of globalisation. With a dramatic spread of media coverage, the spread of NGOs, and global knowledge sharing, the need for companies to conduct business sustainability is the through civil society, customers, governments and shareholders. The reaction of the company also meant a new awareness. Until today, the majority of Bangladeshi companies are family owned and are enterprises of first-generation. Businesses participate in community building activities in the form of a charity, without in many cases a definite spending agenda or sound reasons for financial benefits (Muttakin et al., 2018). It is clear that in the first world, the significance of CSR concerns are yet to be addressed as to how often companies working in developed countries have CSR obligations (Dyduch \& Krasodomska, 2017).

The study exploratory study is conducted on the 'UCB' company. The theoretical results are discussed in everyday CSR management of staff, clients, the community and populations. An analysis is carried out of the Bangladesh residential environment's influences and the global and local environment faced by the MNC. CSR management in the global MNC activities is a qualitative and thorough study using the 'UCB' multinational business as discussed in this paper. The study of selfreported CSR practices in the MNCs showed the global management and cross-border CSR practices and a number of non-transnationally regulated CSR practices across many MNC units and level and several local CSR practices. 
Based on the above discussions, it is possible to conclude that UCB has an acceptable strategy in place for maintaining a healthy corporate culture around CSR and doing business in a socially responsible manner.

- UCB unquestionably fulfils its economic duty to the country by contributing to the national economy as well as to its shareholders by operating a flourishing sector.

- The enforcement status of UCB with the current regulatory agency, as well as the qualification of an independent chartered account company on its Corporate Governance, demonstrate that the bank still fulfils its legal obligations effectively.

- UCB is serious with its ethical obligations, but it requires the firm execution of ethical policies in order to fully adhere to its ethical responsibilities.

- UCB makes a significant effort to its philanthropic activities, but it does not engage in cooperative CSR practices. It only engages in CSR operations to comply with Bangladesh Bank regulations (BB). Furthermore, it only selects sectors for the philanthropic obligation that are recommended by Bangladesh Bank (BB).

- UCB normally practices a top-down control structure in which the board of directors approves all Corporate Social Responsibility programs and lower-level officials only carry them out. As a result, the experiences of staff are not taken into account in the administration of UCB's CSR activities.

- Md. Saiful Islam Khan, Executive Officer at Brand Marketing and Corporate Affairs in UCB, was found to be responsible for coordinating and reporting on UCB's CSR practices; therefore, UCB has unique management staff to coordinate its CSR operations.

- Although UCB organises various training courses for workers during the year, it does not concentrate solely on the bank's CSR activities throughout its training sessions, instead of concentrating on legal and ethical obligations to some degree.

Furthermore, UCB does not advertise its CSR practices to its clients and instead communicates its CSR operations to its shareholders. It just includes CSR events in its annual reports and illustrates CSR tactics on its official website.

\section{Recommendations}

UCB should monitor its CSR activities by including its employees' perspectives and considerations on CSR. Furthermore, implementing the following improvements in the bank's CSR management and activities could have a significant positive effect on its overall CSR practices:

$>$ UCB needs to convey its CSR strategy to its staff more systematically and thoroughly so that they are aware of the breadth of these CSR strategies. It also needs to expand employee interest in the CSR management process.

$>$ Discussions on the bank's CSR activities can be used as an important part of various training sessions.

$>$ UCB will use creative advertising mediums to involve its clients in its CSR operations. As a result, it will improve the efficacy of its CSR activities.

$>\mathrm{UCB}$ will boost its spending on CSR activities as long as it does not have a negative impact on its financial results.

$>\mathrm{UCB}$ has to focus more on its environmental commitments. It may take part in tree planting or fund activities aimed at making cities healthier.

$>$ UCB will concentrate on special development initiatives aimed at farmers, minorities, the green energy industry, and infrastructure development, among other things. It may also create various funds, such as scholarship funds, funds for young entrepreneurs, youth empowerment funds, and so on.

Over and beyond simply adhering to Bangladesh Bank's rules, UCB should consider willingly practising CSR. If UCB wants to be regarded as socially conscious, it should not limit its CSR 
activities to sectors chosen by Bangladesh Bank. As a result, it should extend its philanthropic obligations. Bangladesh has many social problems, which the government cannot solve on its own. As a result, in order to serve their corporate social obligation, UCB stepped forward to participate in societal reformation. Though the bank's commitment is small, it is important, and UCB is commendable as a socially responsible company.

\section{References}

Afshar, A., Polas, R. H., Imtiaz, M., \& Saboor, A. (2019). Customer care service management is moving forward to achieve sustainable customer retention in every industry. Does it play a role to increase brand rentention. International Journal of Management, 8(2), 88-97.

Agudelo, M. A. L., Jóhannsdóttir, L., \& Davídsdóttir, B. (2019). A literature review of the history and evolution of corporate social responsibility. International Journal of Corporate Social Responsibility, 4(1), 1-23.

Ahmed A., Kayssar M. (2013). Corporate Social Responsibility Practices of Commercial Banks in Bangladesh, A Case Study on Southeast Bank Ltd. Journal of Business and Management, 12(1), 13-18. Retrieved from: http://www.iosrjournals.org/iosr-jbm/papers/Vol12issue1/B01211318.pdf

Ali, W., Frynas, J. G., \& Mahmood, Z. (2017). Determinants of corporate social responsibility (CSR) disclosure in developed and developing countries: A literature review. Corporate Social Responsibility and Environmental Management, 24(4), 273-294.

Alshbili, I., \& Elamer, A. A. (2020). The influence of institutional context on corporate social responsibility disclosure: a case of a developing country. Journal of Sustainable Finance \& Investment, 10(3), 269-293.

Barakat, F. S., Pérez, M. V. L., \& Ariza, L. R. (2015). Corporate social responsibility disclosure (CSRD) determinants of listed companies in Palestine (PXE) and Jordan (ASE). Review of Managerial Science, 9(4), 681-702.

Belal, A. R., Cooper, S. M., \& Khan, N. A. (2015). Corporate environmental responsibility and accountability: what chance in vulnerable Bangladesh?. Critical Perspectives on Accounting, 33, 44-58.

Bhattacharjee, A., Polas, M.R.H., Ahmed, M., and Eshita, K.F. (2020). "Alternative Concern on the Remittance Increases Investments and Financial Sustainability", IIUB Studies, A Multidisciplinary Research Journal, Vol. 2, No.1, pp. 29-46.

Bhattacharjee, A. M. I. T. A. B., Polas, M. R. H., \& Rahman, M. L. (2018). Challenges and prospects of tourism in Cox's bazar: An empirical study. Journal of Business and Technology (Dhaka), 13, 63-82.

Carroll A. B. (1991), The Pyramid of Corporate Social Responsibility: Toward the Moral Management of Organizational Stakeholders. Business Horizons, 34(4), 39-48. DOI: https://doi.org/10.1016/0007-6813(91)90005-G

Donaghey, J., \& Reinecke, J. (2018). When industrial democracy meets corporate social responsibility-A comparison of the Bangladesh accord and alliance as responses to the Rana Plaza disaster. British Journal of Industrial Relations, 56(1), 14-42.

DOS Circular No. 01. Department of Off-site Supervision, Bangladesh Bank, Head Office: Dhaka.

Dyduch, J., \& Krasodomska, J. (2017). Determinants of corporate social responsibility disclosure: An empirical study of Polish listed companies. Sustainability, 9(11), 1934.

Hesse-Biber, S. N. (2017). Gunatmak Sanshodhanachi Karyapaddhati. SAGE Publishing India.

Hoque, N., Rahman, A. R. A., Molla, R. I., Noman, A. H. M., \& Bhuiyan, M. Z. H. (2018). Is corporate social responsibility pursuing pristine business goals for sustainable development?. Corporate Social Responsibility and Environmental Management, 25(6), 1130-1142.

Hossain, M. I., Polas, M. R. H., Rahman, M. M., Islam, T., \& Jamadar, Y. (2020). An Exploration of COVID-19 Pandemic and its Consequences on FMCG Industry in Bangladesh. Journal of Management Info, 7(3), 145-155.

Jermsittiparsert, K., Siam, M., Issa, M., Ahmed, U., \& Pahi, M. (2019). Do consumers expect companies to be socially responsible? The impact of corporate social responsibility on buying behavior. Uncertain Supply Chain Management, 7(4), 741-752. 
Javeed, S. A., \& Lefen, L. (2019). An analysis of corporate social responsibility and firm performance with moderating effects of CEO power and ownership structure: A case study of the manufacturing sector of Pakistan. Sustainability, 11(1), 248.

Khan, I., Khan, I., \& Saeed, B. B. (2019). Does board diversity affect quality of corporate social responsibility disclosure? Evidence from Pakistan. Corporate social responsibility and environmental management, 26(6), 1371-1381.

Kuo, T. C., Kremer, G. E. O., Phuong, N. T., \& Hsu, C. W. (2016). Motivations and barriers for corporate social responsibility reporting: Evidence from the airline industry. Journal of Air Transport Management, 57, 184-195.

Majeed, S., Aziz, T., \& Saleem, S. (2015). The effect of corporate governance elements on corporate social responsibility (CSR) disclosure: An empirical evidence from listed companies at KSE Pakistan. International Journal of Financial Studies, 3(4), 530-556.

Mahmud, A., Ding, D., Kiani, A., \& Hasan, M. M. (2020). Corporate Social Responsibility Programs and Community Perceptions of Societal Progress in Bangladesh: A Multimethod Approach. SAGE Open, 10(2), 2158244020924046.

Masud M. A. and Hossain M. S. (2012). Corporate Social Responsibility Reporting Practices in Bangladesh, A Study of Selected Private Commercial Banks. IOSR Journal of Business and Management (IOSR-JBM) ISSN 2278-487X. 6(2), 42-47. Retrieved from: http://iosrjournals.org/iosr-jbm/papers/Vol6-issue2/G0624247.pdf

Miajee, R. K. (2015). Corporate Social Responsibilities Practices in the Government Owned Banking Sector in Bangladesh: A Case Study on Agrani Bank Limited. International Journal of Finance and Banking Research, 1(2), 37-43. Retrieved from: http://article.sciencepublishinggroup.com/html/10.11648.j.ijfbr.20150102.14.html

Moktadir, A., Rahman, T., Jabbour, C. J. C., Ali, S. M., \& Kabir, G. (2018). Prioritisation of drivers of corporate social responsibility in the footwear industry in an emerging economy: A fuzzy AHP approach. Journal of cleaner production, 201, 369-381.

Mocan, M., Rus, S., Draghici, A., Ivascu, L., \& Turi, A. (2015). Impact of corporate social responsibility practices on the banking industry in Romania. Procedia Economics and Finance, 23, 712-716.

Muttakin, M. B., Khan, A., \& Mihret, D. G. (2018). The effect of board capital and CEO power on corporate social responsibility disclosures. Journal of Business Ethics, 150(1), 41-56.

Omran, M. A., \& Ramdhony, D. (2015). Theoretical perspectives on corporate social responsibility disclosure: a critical review. International Journal of Accounting and Financial Reporting, 5(2), 38-55.

Perry, P., Wood, S., \& Fernie, J. (2015). Corporate social responsibility in garment sourcing networks: Factory management perspectives on ethical trade in Sri Lanka. Journal of Business Ethics, 130(3), 737-752.

Polas, M.R.H., Raju, V., Muhibbullah, M. and Tabash, M.I. (2021), "Rural women characteristics and sustainable entrepreneurial intention: a road to economic growth in Bangladesh", Journal of Enterprising Communities: People and Places in the Global Economy. https://doi.org/10.1108/JEC-10-2020-0183

Polas, M. R. H., Raju, V., Hossen, S. M., Karim, A. M., \& Tabash, M. I. (2020). Customer's revisit intention: Empirical evidence on Gen-Z from Bangladesh towards halal restaurants. Journal of Public Affairs, e2572. https://doi.org/10.1002/pa.2572

Rahman, A. (2013). Evolution of CSR in Bangladesh and future challenges. CSR Review, 10, 1-4

Rana, M. M., Kalam, A., Halimuzzaman, M., Kalam, A., \& Halimuzzaman, M. (2012). Corporate social responsibility (CSR) of Dutch-Bangla Bank Limited: A case study. Bangladesh Research Publication Journal, 7(3), 241-247.

Rao, K., \& Tilt, C. (2016). Board composition and corporate social responsibility: The role of diversity, gender, strategy and decision making. Journal of Business Ethics, 138(2), 327-347

Rezaul K. (2017, 9 January). CSR guideline in the offing. The Financial Express. Retrieved from: http://www.thefinancialexpress-bd.com/2017/01/09/58616/CSR-guideline-in-the-offing

Review of CSR activities of Bangladesh Bank, Commercial Banks and Financial Institutions2014, Retrieved from: https://www.bb.org.bd/pub/publictn.php 
Shen, L., Govindan, K., \& Shankar, M. (2015). Evaluation of barriers of corporate social responsibility using an analytical hierarchy process under a fuzzy environment-A textile case. Sustainability, 7(3), 3493-3514.

Tilt, C. A. (2016). Corporate social responsibility research: the importance of context. International Journal of Corporate Social Responsibility, 1(1), 1-9.

Uddin, S., Siddiqui, J., \& Islam, M. A. (2018). Corporate social responsibility disclosures, traditionalism and politics: A story from a traditional setting. Journal of Business Ethics, 151(2), 409-428.

United Commercial Bank Ltd. (UCB) (2015). Annual Report of UCB 2015. Retrieved from: http://www.ucb.com.bd/index.php?page=know-ucb/reports-and-statements

Yasmin F. (2016, December 04-05). Limitations of CSR and scopes of social business in the banking industry of Bangladesh. Paper presented at the Proceedings of the $5^{\text {th }}$ Annual Banking Conference of Bangladesh Institute of Bank Management (BIBM), Dhaka. 